\title{
Can We Improve the Salinity Tolerance of Genotypes of Taxodium by Using Varietal and Hybrid Crosses?
}

\author{
Lijing Zhou and David L. Creech ${ }^{\mathbf{1}}$ \\ Arthur Temple College of Forestry and Agriculture, Stephen F. Austin State \\ University, $T X 75962$
}

Ken W. Krauss

U.S. Geological Survey, National Wetlands Research Center, 700 Cajundome

Boulevard, Lafayette, LA 70506

Yin Yunlong

Institute of Botany of Jiangsu Province and the Chinese Academy of Sciences, Nanjing 210014, P.R. China

\author{
David L. Kulhavy \\ Arthur Temple College of Forestry and Agriculture, Stephen F. Austin State \\ University, $T X 75962$
}

Additional index words. Taxodium distichum, baldcypress, Montezuma cypress, Taxodium distichum, 'Nanjing Beauty' (T 302), hybrid, salt tolerance, var. distichum, var. mexicanum

\begin{abstract}
Taxodium distichum (L.) Rich. var. distichum [baldcypress (BC)], Taxodium distichum var. mexicanum Gordon [Montezuma cypress (MC)], and a Taxodium hybrid ('Nanjing Beauty': BC $\times$ MC cross, T302) were evaluated for salt tolerance in 2006 at Nacogdoches, TX. Plants were irrigated weekly with four levels of salinity $[0,1,3.5$, and $6 \mathrm{ppt}\left(0,17,60\right.$, and $\left.\left.102 \mathrm{~mol} \cdot \mathrm{m}^{-3}\right)\right]$ for 13 weeks and then $0,2,7$, and $12 \mathrm{ppt}(0,34,120$, and $204 \mathrm{~mol} \cdot \mathrm{m}^{-3}$ ) for another 12 weeks. Salinity treatments did not have a significant effect on growth rate; however, there were significant differences in growth rate among the three genotypes. Genotype T302 produced the greatest wet weight, whereas MC had stronger apical dominance and exhibited the greatest increase in height over the course of study. As expected, sodium (Na) concentration in Taxodium leaves increased as sea salt concentrations increased but did not tilt $\mathrm{Na}$ /potassium $(\mathrm{K})$ ratios to stressful disproportions. Of the three genotypes, $\mathrm{BC}$ exhibited the highest leaf content of $\mathrm{Na}$, calcium $(\mathrm{Ca})$, sulfur (S), and iron (Fe); MC had the lowest leaf content of $\mathrm{Na}, \mathrm{Ca}, \mathrm{S}$, and $\mathrm{Fe}$; and $\mathrm{T302}$ was intermediate. The benefits of using a hybrid cross (T302) that maintains greater biomass than $\mathrm{BC}$ or $\mathrm{MC}$ across a range of salinities must be weighed against the potential additional pruning and training necessary for cutting-grown clones relative to $\mathrm{BC}$ and MC propagated from seed and flood tolerance relative to $\mathrm{BC}$. Still, combining the best characteristics of different varieties of $T$. distichum should facilitate the production of favorable genotypes tolerant to a number of soil physical and chemical property fluctuations for arboricultural operations.
\end{abstract}

Many coastal wetlands of the southeastern United States are threatened by increases in flooding and salinity as a result of both natural processes and man-induced hydrologic alterations (Allen, 1992; Conner and Toliver, 1990; Craig et al., 1979; Templet and Meyer-Arendt,

\footnotetext{
Received for publication 2 Mar. 2010. Accepted for publication 13 Sept. 2010.

This project was partially supported by a University Research Council award, Stephen F. Austin State University, Nacogdoches, TX (2006-2008).

We are thankful to Kenneth W. Farrish and Donald B. Pratt for their comments on earlier drafts. We thank Richard H. Day and Larry K. Allain for commenting on a previous version of this manuscript. Any use of trade, product, or firm names is for descriptive purposes only and does not imply endorsement by the U.S. Government.

${ }^{1}$ To whom reprint requests should be addressed; e-mail dcreech@sfasu.edu.
}

1988; Wicker et al., 1981). Of all native swamp forest tree species in the southern United States, Taxodium distichum has been recognized as being among the most tolerant to flooding (Hook, 1984) and salinity (Krauss et al., 2007). Taxodium distichum is an important wetland species of river and coastal floodplains, harboring resilience to windthrow (Conner et al., 2002) and providing a number of important forest products (Mattoon, 1915). In addition, this long-lived and generally pestfree deciduous conifer is popular in southern landscapes and is also quite tolerant of alkalinity (Arnold, 2008), which is responsible in part for its expanding distribution as a roadside and public park landscape tree in the United States and China. The combination of Taxodium characteristics described to date provides great opportunity for locating superior genotypes and propagating clones that fit a range of potential site requirements.
Previous literature often refers to three separate species of Taxodium: Taxodium distichum (baldcypress), T. ascendens (pondcypress), and T. mucronatum (Montezuma cypress). Although the taxonomic relationships among these three species, or varieties, of Taxodium remain a source of debate (Tsumura et al., 1999), the ranges of baldcypress and pond cypress overlap and these two have been recognized as possibly being two varieties of $T$. distichum (Integrated Taxonomic Information System, 2009). For the purpose of this study, we have accepted the nomenclature that combines all Taxodium associates into one species with three botanical varieties (Arnold and Denny, 2007), as follows: Taxodium distichum var. distichum (L.) Rich (BC); Taxodium distichum var. imbricarium (Nutt.) Croom [pondcypress (PC)]; and Taxodium distichum var. mexicanum Gordon (MC).

There has been considerable work in China that has involved controlled crosses between $\mathrm{BC}, \mathrm{MC}$, and PC, and the subsequent selection of superior genotypes that are multiplied through cutting propagation. T302 $(\mathrm{BC} \times \mathrm{MC})$ was selected in China in 1988 primarily for growth rate and tolerance to alkaline and saltrich coastal floodplains. T302 is registered at both the provincial and federal level and accepted for higher salt tolerance than $\mathrm{BC}$ and PC. Other attributes of T302 included 159\% faster growth than $\mathrm{BC}$, good form, longer foliage retention in fall and early winter, and no knees (Chen et al., 1987). Huang et al. (2006) reported that the growth of T302 had strong adaptability to a wide range of soils and climate.

Li (2006) completed a genetic analysis of 18 Taxodium genotypes and found considerable diversity using random amplified polymorphic DNA. According to cluster analysis, the results indicated that $\mathrm{BC}$ and $\mathrm{PC}$ are genetically nearer, whereas $\mathrm{T} 302$ is genetically closer to $\mathrm{BC}$. Yu et al. (2009) completed the identification of Taxodium hybrids by sequence-related amplified polymorphism (SRAP) analysis. In this study, the authenticity of 4 reciprocal progenies from Taxodium distichum and T. mucronatum were identified by SRAP markers. Authenticity of four progenies from $T$. distichum and T. mucronatum was identified by 12 polymorphism primer combinations. The results indicated that four progenies were true hybrids resulting from specific bands from the male parent.

Past studies that have used only $\mathrm{BC}$ genotypes found evidence for modest potential gains in salt tolerance improvement in the species (Allen et al., 1994a, 1997; Krauss et al., 2000) but with almost complete mortality of all $\mathrm{BC}$ genotypes at salinities above $6 \mathrm{ppt}\left(102 \mathrm{~mol} \cdot \mathrm{m}^{-3}\right)$ in as little as 30 to $90 \mathrm{~d}$ (Krauss et al., 2007). Those studies primarily focused on selecting plant material for coastal restoration efforts in wetland settings and therefore did not include MC, which is far less tolerant to flooding and is not native to the southeastern United States. Denny (2007) conducted a greenhouse salinity screening study to determine if there is a geographic basis for salinity tolerance in Taxodium and to evaluate provenances in an effort to select those that 
yield individuals that are most adaptable/ tolerant to these environmental stresses. The results indicated that most genotypes tolerate moderate levels of soil salts, but at high soil salinities, the tolerance appears to be highly genotype-dependent. While more salt tolerant, MC genotypes are generally more susceptible to Cercospora needle blight (McDonald et al., 2008). In this study, we evaluated growth and leaf nutrient changes in three Taxodium genotypes (BC, MC, and one $\mathrm{BC} \times \mathrm{MC}$ hybrid) exposed to acute applications of four rates of salt solution. Arboricultural operations might certainly benefit from combining the best characteristics of these disparate Taxodium distichum genotypes as a mechanism for improving growth and productivity on salt-impacted, or otherwise stressful, sites outside of wetland settings. Selections based on growth rate, form, salt and alkalinity tolerance, tolerance to inundation, and other characteristics are certain to have an audience with land use planners, horticulturists, and foresters seeking long-lived urban trees with those attributes.

\section{Material and Methods}

Plant material. Three genotypes representing two varieties $(\mathrm{BC}, \mathrm{MC})$ and one hybrid (T302) of Taxodium were evaluated. BC seed was collected from a natural source near Caddo Lake, TX, and MC seed was obtained from a nurseryman who reported to have originally collected seed from trees south of Las Cruces, $\mathrm{NM}$, in a mountain canyon. Although that population provenance has yet to be verified, the trees are strongly MC in appearance, foliage, habit, growth, and seed size. Hybrid T302 (or 'Nanjing Beauty'; Creech and Yin, 2003) represents a cross between $B C$ and $M C$ and was propagated from cuttings of existing trees for this study. T302 has been described as having improved alkalinity and salinity tolerance (Chen et al., 1987; Zhou et al., 2000), a major reason for its use in this study. Ninetysix plants per genotype were planted in 7.6-L plastic nursery pots containing a commercial potting substrate (Woods \#2; Bailey Bark Materials, Woden, TX). Nutrient content of the mix was analyzed in the SFASU Soil and Plant Tissue Testing Laboratory (Table 1). Although most of the substrate parameters are acceptable, background conductivity was considered moderately high at the initiation of the experiment but quickly stabilized. The containers were placed under full sunlight at the Pineywoods Native Plant Center nursery, Stephen F. Austin State University, Nacogdoches, TX, and grown for $60 \mathrm{~d}$ to a height of $\approx 25 \mathrm{~cm}$ before experimental treatments were imposed.

Experimental design. The experiment used a two-way factorial design with three Taxodium genotypes and four levels of salinity arranged as a completely randomized block with four blocks. Six plants per genotype were randomly assigned to each treatment for a total of 24 plants per genotype in each of the four replicate blocks. In this case, blocks served as true experimental replicates with each block serving as an independently maintained experimental unit for a total of 288 plants in the entire study.

Experimental procedures. Initial treatments included a control with no sea salt (C), a low salt concentration of $1 \mathrm{ppt}\left(\mathrm{L}: 17 \mathrm{~mol} \cdot \mathrm{m}^{-3}\right)$, a medium salt concentration of $3.5 \mathrm{ppt}(\mathrm{M}$ : $60 \mathrm{~mol} \cdot \mathrm{m}^{-3}$ ), and a high salt concentration of 6 ppt (H: $102 \mathrm{~mol} \cdot \mathrm{m}^{-3}$ ). The chemical composition of the artificial sea salt used (SaltWorks ${ }^{\mathrm{TM}}$, Woodinville, WA) mimics that of actual sea water in concentrations of major ions (Table 2).

Sea salt application was initiated on 22 May 2006 and was intended to simulate repetitive, acute exposure to roots but to allow for some flushing as well as some cumulative build-up of salinity within pots. Only substrate salinity tolerance was tested in this container study. From experimental initiation, $500 \mathrm{~mL}$ of each sea salt solution (i.e., C, L, M, H) was applied to the surface of each respective container every Monday afternoon for 13 weeks. After 13 weeks of salt application, no salt damage symptoms were noticed in the appearance of the trees. For this reason, the salt concentration rates were doubled beginning on 21 Aug. 2006; concentrations were increased to $0,2,7,12 \mathrm{ppt}\left(0,34,120\right.$, and $\left.204 \mathrm{~mol} \cdot \mathrm{m}^{-3}\right)$ for treatments $\mathrm{C}, \mathrm{L}, \mathrm{M}$, and $\mathrm{H}$, respectively. The same application procedure was followed every Monday afternoon using these new concentrations, once per week, for another 12 weeks until 7 Nov. 2006.

Salt solutions remained in containers for at least $24 \mathrm{~h}$ after each salt application before irrigation with city water, which has low conductivity (less than $0.35 \mathrm{dS} \cdot \mathrm{m}^{-1}$ ) and $\mathrm{Na}$ below $50 \mathrm{ppm}$ (data not shown). The plants were watered as needed with overhead sprinklers for $\approx 40$ min per irrigation; plants were watered in this fashion two to three times per week to simulate horticultural irrigation. Plants were fertilized with $12.8 \mathrm{~g}$ of a slowrelease $18 \mathrm{~N}-6 \mathrm{P}-12 \mathrm{~K}$ fertilizer $\left(\right.$ Osmocote ${ }^{\circledR}$; Scotts Miracle-Gro Company, Marysville, $\mathrm{OH}$ ) on 14 June 2006. Electrical conductivity (EC) of the leachate flowing out of the treatment pots was measured with a portable Myronl Agri-meter (Model ag-5; Myronl Company, Carlsbad, CA) as an indication of salt retention within sample pots.

Tissue analysis. Leaf samples were collected for foliar nutrient analysis on 27 Oct. 2006, just before the last salt application. Six leaves were taken as subsamples from each plant for a total of 36 leaves per genotype per treatment in each block. The plant samples were dried to a constant weight in a convection oven for $3 \mathrm{~d}$ at $60^{\circ} \mathrm{C}$. Dried subsample leaves were pooled by treatment combination to ensure adequate volume of material for analysis, generating a total of 288 samples after pooling. Samples were then ground in a cyclone grinder, homogenized, and analyzed for nutrient concentration. A nitric acid $\left(\mathrm{HNO}_{3}\right)$ and $30 \%$ hydrogen peroxide wet acid digestion was used to prepare the samples for phosphorus $(\mathrm{P}), \mathrm{K}, \mathrm{Na}, \mathrm{Ca}$, and magnesium $(\mathrm{Mg})$ analysis using inductively coupled argon plasma spectroscopy (IRIS Intrepid Inductively Coupled Argon Plasma Training Manual, Thermo Electron Corporation, Franklin, MA).
Table 1. Potting substrate analysis based on saturated extract using deionized water.

\begin{tabular}{lrlr}
\hline pH & 7.01 & Magnesium & 47.60 \\
EC & 2.10 & Sodium & 110.99 \\
SAR & 1.92 & Iron & 1.03 \\
Nitrogen & 1.00 & Manganese & 0.43 \\
Phosphorus & 10.67 & Zinc & 0.07 \\
Potassium & 257.27 & Copper & 0.04 \\
Calcium & 191.94 & & \\
\hline
\end{tabular}

$\mathrm{EC}=$ electrical conductivity $\left(\mathrm{dS} \cdot \mathrm{m}^{-1}\right) ;$ ion concentrations reported in $\mathrm{mg} \cdot \mathrm{L}^{-1} ; \mathrm{SAR}=$ sodium absorption ratio. Values represent means of three replicates.

Table 2. Chemical composition of the sea salt used in the experiment.

\begin{tabular}{lc}
\hline Components & Typical range (\%) \\
\hline $\mathrm{NaCl}$ & $99.50-99.88$ \\
Calcium & $0.02-0.06$ \\
Magnesium & $0.01-0.05$ \\
$\mathrm{SO}_{4}$ & $0.05-0.21$ \\
\hline
\end{tabular}

Heights and wet weights. Plant heights were measured for each plant at the beginning and conclusion of the experiment. Each plant was cut back to $5 \mathrm{~cm}$ above ground and the above-ground parts were weighed (grams wet weight) as a measure of the capacity for individual plant performance under the different experimental treatments.

Data analysis. The General Linear Model (GLM) procedure of SAS (SAS Institute, Inc., 2007) was used to detect significant differences in plant height, wet weight, and tissue nutrient concentrations for the different genotypes and treatments. Data were analyzed as a full-factorial using mean square error; interactions between genotype and salinity were also tested. A Tukey's studentized range test ( $\alpha=$ 0.05 ) with a Bonferroni adjustment to account for sample size effects was used to identify statistical groupings if a significant effect was detected with GLM analysis. Data were normally distributed with homoscedastic variance without the need for transformation.

\section{Results and Discussion}

Electrical conductivity. EC readings identified rapid and consistent leaching of salinity from pots in as little as $2 \mathrm{~d}$ (Fig. 1). When sea salt application rates were doubled, essentially the ECs also doubled (data not shown), but the leaching rates after application were similar. During the 24-h exposure period each week, roots were subjected to conductivities as high as $20 \mathrm{dS} \cdot \mathrm{m}^{-1}$ for the high salt solution. Although our study did not simulate a natural wetland setting, it is important to note how freely salinity exits substrate in container situations (Fig. 1). Salinity often remains at elevated levels for months (or even years) after hurricane overwash in coastal swamp forests (Conner et al., 2007). As simulated here in this acute exposure study, leaching rates are expected to be much greater in the less saturated substrate used; as a result, exposure to salinity occurred only $15 \%$ of growth time in our simulation. Many coastal swamp forests are 
no longer freely flushed with river water, forcing an important distinction between chronic exposure in natural wetland field settings and acute simulations in roadside environments or controlled landscapes where deicing salts, fertilizer salts, or limestone applications may be present.

Growth. Wet weights of T. distichum genotypes did not differ significantly among the various concentrations of sea salt tested by our experiment (Table 3); however, wet weights were different among the three genotypes when analyzed across all four concentrations of sea salt (Tables 3 and 4). Although wet weights were collected at the completion of the experiment, dry weight/wet weight ratios of whole plants were developed at a later date, with BC, MC, and T302 averaging 0.32, 0.33, and 0.25 , respectively. When adjusted wet weight/dry weight ratios were applied to the data set in this study, the significance among comparisons remained unchanged (Table 3). Because interactions between salinity and genotype were also not significant for either wet weight or height growth (Table 3), it is feasible to evaluate salinity effects across all genotypes.

First, although the T. distichum genotypes were exposed to salinities that would have certainly been detrimental to growth with chronic exposure (Conner, 1994; Krauss et al., 1999; Pezeshki, 1990; Pezeshki et al., 1986, 1987), the acute pulses of salinity at concentrations up to 6 and 12 ppt had no effect on the wet weights of plants in our study. This indicates that exposure to short pulses of salinity, as might be expected by deicing salts along roadsides, or an infrequent misapplication of a fertilizer or limestone product in the landscape, would have small effects on the genotypes if they were flushed within days of application. This result also indicates that salinity exposure in our study may not have been high enough to warrant major differences among genotypes. However, the mean wet weight of T302 was significantly greater than wet weights of both $\mathrm{BC}$ and $\mathrm{MC}$ across all four salinity treatments (Table 4). This result, the fact that genotypic rank did not change with increased salinity exposure (Table 3), indicates that T302 tended to perform better without regard to our salinity treatments and perhaps would even be expected to perform better under a range of environmental conditions beyond salinity. In support of this idea, volume growth of T302 was $331 \%$ of BC for T302 grown on an alkaline low-land area in China (Zhou et al., 2000).

Second, differences were also not detected in $T$. distichum height growth with different sea salt exposures, but similar to wet weights, significant differences in height growth were detected among genotypes (Table 4). On the other hand, MC, not T302, ranked highest in terms of height growth increment followed by BC. There were still no interactive effects between salinity treatments and genotypes (Table 3), suggesting that rankings once again transcended salinity treatment.

These data identify a potential hurdle when using hybrids in that although biomass may be high under a range of salinity exposures, apical dominance, which is a major characteristic of
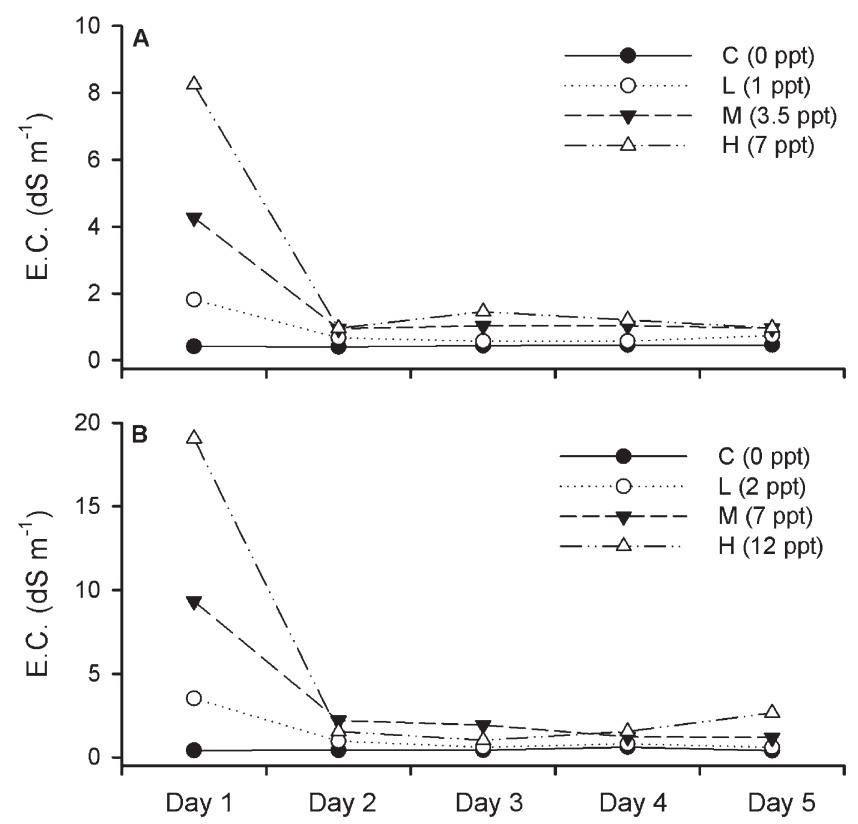

Fig. 1. Electrical conductivity (EC) $\left(\mathrm{dS} \cdot \mathrm{m}^{-1}\right)$ measurements of pot leachate over a representative 5-d cycle after application of (A) $500 \mathrm{~mL}$ of $0 \mathrm{ppt}(\mathrm{C}), 1 \mathrm{ppt}(\mathrm{L}), 3.5 \mathrm{ppt}(\mathrm{M})$, and $6 \mathrm{ppt}(\mathrm{H})$ sea salt solution; and (B) $500 \mathrm{~mL}$ of $0 \mathrm{ppt}(\mathrm{C}), 2 \mathrm{ppt}(\mathrm{L}), 7 \mathrm{ppt}(\mathrm{M})$, and $12 \mathrm{ppt}(\mathrm{H})$ sea salt solution. Day 1 reflects application day. Values represent one random sample collected per day per treatment.

Table 3. General linear model analysis of variance for (A) mean wet weight and (B) adjusted dry weight, ${ }^{z}$ and (C) height of Taxodium genotypes exposed to different sea salt application rates.

\begin{tabular}{|c|c|c|c|c|c|}
\hline \multicolumn{5}{|l|}{ A. Wet weight } & $\operatorname{Pr}>F$ \\
\hline Salinity & 3 & 14867.26 & 4955.75 & 2.65 & 0.1122 \\
\hline Genotype & 2 & 464224.56 & 232112.28 & 32.72 & 0.0006 \\
\hline Salinity $\times$ genotype & 6 & 21670.38 & 3611.73 & 1.04 & 0.4339 \\
\hline \multicolumn{6}{|c|}{ B. Adjusted dry weight } \\
\hline Salinity & 3 & 7479.15 & 2493.05 & 2.55 & 0.1214 \\
\hline Genotype & 2 & 192991.27 & 96495.61 & 20.13 & 0.0022 \\
\hline Salinity $\times$ genotype & 6 & 13119.79 & 2186.63 & 1.11 & 0.3930 \\
\hline \multicolumn{6}{|l|}{ C. Height } \\
\hline Salinity & 3 & 69.15 & 23.05 & 0.69 & 0.5829 \\
\hline Genotype & 2 & 9611.94 & 4805.97 & 51.68 & 0.0002 \\
\hline Salinity $\times$ genotype & 6 & 281.12 & 46.85 & 0.97 & 0.4700 \\
\hline
\end{tabular}

${ }^{2}$ Adjusted dry weight value was derived from subsequent studies with dry weight/wet weight ratios of whole plants obtained from similar size material with baldcypress, Montezuma cypress, and T302 averaging $0.32,0.33$, and 0.25 , respectively.

Table 4. Mean biomass (g wet wt) and height increment $(\mathrm{cm})$ of three genotypes of Taxodium at a sea salt application of $0 \mathrm{ppt}(\mathrm{C}), 1 \mathrm{ppt}(\mathrm{L}), 3.5 \mathrm{ppt}(\mathrm{M})$, and $6 \mathrm{ppt}(\mathrm{H})$ for 13 weeks, and then $0 \mathrm{ppt}(\mathrm{C}), 2 \mathrm{ppt}(\mathrm{L})$, $7 \mathrm{ppt}(\mathrm{M})$, and $12 \mathrm{ppt}(\mathrm{H})$ for an additional 12 weeks.

\begin{tabular}{lrlrlllr}
\hline & \multicolumn{3}{c}{ Wet wt } & & \multicolumn{3}{c}{ Ht } \\
\cline { 2 - 4 } \cline { 7 - 8 } Rate & BC & T 302 & MC & & BC & T 302 & MC \\
\hline C & 55.32 & 61.44 & 87.88 & & 55.32 & 61.44 & 87.88 \\
L & 50.95 & 68.02 & 91.77 & & 50.95 & 68.02 & 91.77 \\
M & 53.21 & 69.82 & 86.51 & & 53.21 & 69.82 & 86.51 \\
H & 52.96 & 72.8 & 89.38 & & 52.96 & 72.8 & 89.38 \\
Mean & $53.11 \mathrm{c}$ & $68.02 \mathrm{~b}$ & $88.90 \mathrm{a}$ & $53.11 \mathrm{c}$ & $68.02 \mathrm{~b}$ & $88.90 \mathrm{a}$ \\
\hline
\end{tabular}

Means followed by the same letter in groups are not significantly different at the 0.05 level of probability according to Tukey's studentized range test.

$\mathrm{BC}=$ baldcypress $\mathrm{MC}=$ Montezuma cypress .

natural $T$. distichum trees propagated from seed, is compromised. T302 had the greatest wet weight, but MC had the greatest height growth during salinity exposure. This is best explained by the fact that T302 was derived by rooted cuttings, which often exhibit plagiotro- pic growth with more branching, whereas MC, derived from seed, quickly formed a strong central leader with less branching. Because T302 is commonly propagated by cuttings, and there are many more lateral branches available for sources of cuttings than apical 
stems, the result is often propagated trees that act like branches when planted, at least initially (Zobel and Talbert, 1984). In China, nurserymen have developed a protocol for nursery propagation and production of such clones. They typically grow cutting-propagated liners in the field for 1 year with little pruning. In the winter, the tree is cut to 6 inches above the ground and side limbs pruned away. Vigorous growth resumes in the spring, a leader quickly forms, and numerous vigorous, mostly upright cuttings are available for cutting propagation in the summer. One vigorous upright shoot is left to create the leader, which results in a tall, well-formed, and marketable tree by winter. Although plagiotrophy can be a benefit for fruit culture to reduce the time from planting to fruit production, for example, silvicultural operations have fewer uses for spindly growth patterns outside of seed orchards, with the exception perhaps of hedge rows or coastal vegetation barriers. An appropriate role for T302 or other hybrids will need to be identified, but it appears to be the most productive of the three genotypes tested under this type of salinity exposure.

Leaf tissue content. Leaf tissue elemental concentrations also differed among genotypes (Table 5). Of the three genotypes studied here, $\mathrm{BC}$ had a higher content of $\mathrm{Ca}, \mathrm{Na}, \mathrm{S}$, and $\mathrm{Fe}$ in the foliage than $\mathrm{MC}$, suggesting that $\mathrm{BC}$ takes up some ions associated with salinity more readily than MC. A failure to exclude $\mathrm{Na}$ and additional ions from leaf tissue can readily lead to increased osmotic stress, ion toxicity, or ion and hormone imbalances (Flowers et al., 1977; Greenway and Munns, 1980). By all appearances, MC had a greater capacity for excluding deleterious ions such as $\mathrm{Na}$ than $\mathrm{BC}$; ion exclusion is likely to be an important mechanism for increasing salt tolerance in baldcypress even among individual populations of BC (Allen et al., 1996). As foliar Na concentrations increase in $\mathrm{BC}$, the photosynthetic capacity of BC decreases linearly (Pezeshki et al., 1988). The hybrid (T302) registered intermediate foliar concentrations for $\mathrm{Na}$ but grouped with $\mathrm{BC}$ for $\mathrm{K}, \mathrm{Ca}, \mathrm{S}$, and $\mathrm{Fe}$ (Fig. 2). Likewise, foliar $\mathrm{K}, \mathrm{Ca}, \mathrm{Na}, \mathrm{S}$, and $\mathrm{Fe}$ were significantly higher in $\mathrm{BC}$ and $\mathrm{T} 302$ than in MC with T302 having the highest foliar content of $\mathrm{P}, \mathrm{Mg}$, zinc, and copper.

We found significant differences of leaf elemental content of $\mathrm{Na}$ among treatments in this study $(\mathrm{F}=18.62 ; P=0.0003$; Table 6$)$. Foliar K concentrations in treatment L were significantly lower than at the sea salt concentrations for treatments $\mathrm{M}$ and $\mathrm{H}(\mathrm{F}=5.52 ; P=$ 0.0199; Table 6). Of four salinity treatments, leaf $\mathrm{S}$ concentration in Taxodium at $\mathrm{L}$ was significantly higher than in $\mathrm{H}(\mathrm{F}=4.77 ; P=$ 0.0295; Table 6). Leaf $\mathrm{Na}$ concentration at L, M, and $\mathrm{H}$ was $146 \%, 200 \%$, and $269 \%$, respectively, that of $\mathrm{C}$. In addition, leaf ion $\mathrm{Na}$ / $\mathrm{K}$ ratios peaked at only 0.28 for $\mathrm{H}$, offering further insight into why we observed no visible signs of stress in T. distichum initially. Uptake of the salts to the leaves was not proportional to sea salt concentrations applied, suggesting that differential uptake and/or exclusion of salts by plants may be occurring. Exclusion

Table 5. Leaf foliar nutrient concentrations for all three genotypes of Taxodium subjected to a range of sea salt exposure.

\begin{tabular}{|c|c|c|c|c|c|c|c|c|c|c|}
\hline & $\begin{array}{c}\text { Phosphor } \\
\text { (\%) }\end{array}$ & $\begin{array}{c}\text { otassiu } \\
(\%)\end{array}$ & $\begin{array}{c}\text { Calciu } \\
(\%)\end{array}$ & $\begin{array}{c}\text { agnesi } \\
(\%)\end{array}$ & $\begin{array}{c}\text { Sodiun } \\
(\%)\end{array}$ & $\begin{array}{l}\text { Sulfur } \\
(\%)\end{array}$ & $\begin{array}{c}\text { Iron } \\
\left(\mathrm{mg} \cdot \mathrm{L}^{-1}\right)\end{array}$ & $\begin{array}{l}\text { Manganese } \\
\left(\mathrm{mg} \cdot \mathrm{L}^{-1}\right)\end{array}$ & $\begin{array}{c}\text { Zinc } \\
\left(\mathrm{mg} \cdot \mathrm{L}^{-1}\right)\end{array}$ & $\begin{array}{c}\text { Copper } \\
\left(\mathrm{mg} \cdot \mathrm{L}^{-1}\right)\end{array}$ \\
\hline$\overline{\mathrm{BC}}$ & $0.21^{z} b^{y}$ & $1.35 \mathrm{a}$ & $1.11 \mathrm{a}$ & $0.14 \mathrm{~b}$ & $0.39 \mathrm{a}$ & $0.21 \mathrm{a}$ & $65.06 \mathrm{a}$ & $49.87 \mathrm{~b}$ & $23.12 \mathrm{c}$ & $5.12 \mathrm{~b}$ \\
\hline T302 & $0.29 \mathrm{a}$ & $1.46 \mathrm{a}$ & $1.08 \mathrm{a}$ & $0.17 \mathrm{a}$ & $0.23 \mathrm{~b}$ & $0.19 \mathrm{a}$ & $58.06 \mathrm{a}$ & $65.81 \mathrm{a}$ & $47.19 \mathrm{a}$ & $7.06 \mathrm{a}$ \\
\hline MC & $0.26 \mathrm{a}$ & $0.79 \mathrm{~b}$ & $0.79 \mathrm{~b}$ & $0.14 \mathrm{~b}$ & $0.09 \mathrm{c}$ & $0.16 \mathrm{~b}$ & $43.37 \mathrm{~b}$ & $66.94 \mathrm{a}$ & $35.37 \mathrm{~b}$ & $5.31 \mathrm{ab}$ \\
\hline
\end{tabular}

${ }^{\mathrm{z}}$ Values are means of 92 samples.

${ }^{y}$ Means within a column followed by the same letter are not significantly different at the 0.05 level of probability according to Tukey's studentized range test.

$\mathrm{BC}=$ baldcypress; $\mathrm{MC}=$ Montezuma cypress.

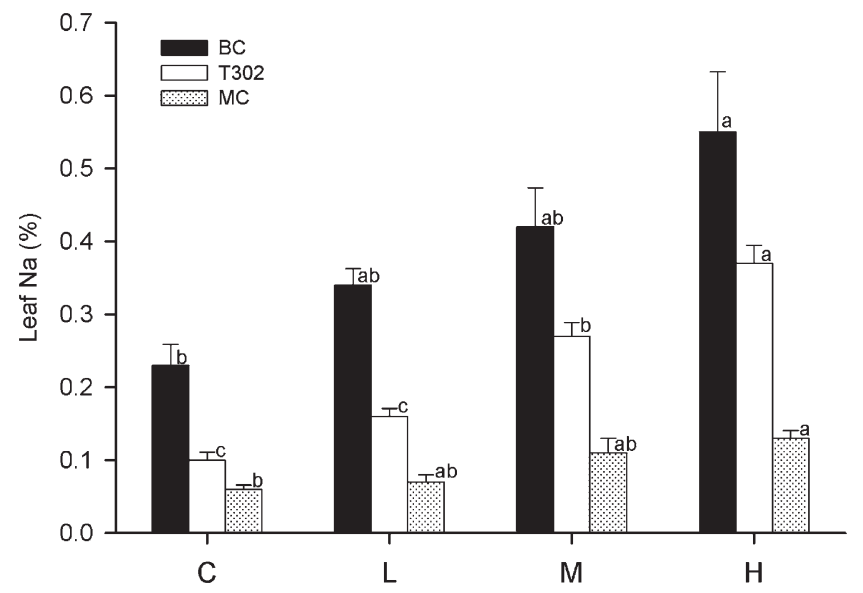

Fig. 2. Concentrations of leaf sodium (Na) (\%) for baldcypress (BC), Montezuma cypress (MC), and T302 exposed to $0 \mathrm{ppt}(\mathrm{C}), 1 \mathrm{ppt}(\mathrm{L}), 3.5 \mathrm{ppt}(\mathrm{M})$, and $6 \mathrm{ppt}(\mathrm{H})$ sea salt solution for 13 weeks, and then $0 \mathrm{ppt}$ (C), $2 \mathrm{ppt}(\mathrm{L}), 7 \mathrm{ppt}(\mathrm{M})$, and $12 \mathrm{ppt}(\mathrm{H})$ sea salt solution for an additional 12 weeks. Values are means of 24 samples. Bars represent 1 SD of the mean. Means for a particular genotype (BC, MC, or T302) represented by the same letter among treatment $(\mathrm{C}, \mathrm{L}, \mathrm{M}$, or $\mathrm{H})$ are not significantly different at the 0.05 level of probability according to Tukey's studentized range test.

Table 6. Leaf foliar nutrient concentrations (\%) of all Taxodium genotypes subjected to sea salt application of $0 \mathrm{ppt}(\mathrm{C}), 1 \mathrm{ppt}(\mathrm{L}), 3.5 \mathrm{ppt}(\mathrm{M})$, and $6 \mathrm{ppt}(\mathrm{H})$ for 13 weeks, and then $0 \mathrm{ppt}(\mathrm{C}), 2 \mathrm{ppt}(\mathrm{L}), 7 \mathrm{ppt}(\mathrm{M})$, and $12 \mathrm{ppt}(\mathrm{H})$ for an additional 12 weeks.

\begin{tabular}{lcccccc}
\hline Rate & Phosphorus & Potassium & Calcium & Magnesium & Sulfur & Sodium \\
\hline $\mathrm{C}$ & $0.26 \mathrm{a}$ & $1.22 \mathrm{ab}$ & $0.97 \mathrm{a}$ & $0.15 \mathrm{a}$ & $0.18 \mathrm{ab}$ & $0.13 \mathrm{c}$ \\
$\mathrm{L}$ & $0.25 \mathrm{a}$ & $1.09 \mathrm{~b}$ & $1.04 \mathrm{a}$ & $0.15 \mathrm{a}$ & $0.19 \mathrm{a}$ & $0.19 \mathrm{bc}$ \\
$\mathrm{M}$ & $0.25 \mathrm{a}$ & $1.23 \mathrm{a}$ & $1.04 \mathrm{a}$ & $0.15 \mathrm{a}$ & $0.18 \mathrm{ab}$ & $0.26 \mathrm{ab}$ \\
$\mathrm{H}$ & $0.25 \mathrm{a}$ & $1.25 \mathrm{a}$ & $0.93 \mathrm{a}$ & $0.14 \mathrm{a}$ & $0.17 \mathrm{~b}$ & $0.35 \mathrm{a}$ \\
\hline
\end{tabular}

Means within a column followed by the same letter are not significantly different at the 0.05 level of probability according to Tukey's studentized range test.

of ions, especially chlorine, has been suggested as a primary mechanism for salt tolerance among non-halophytic trees (Allen et al., 1994b; Townsend, 1989). There was no significant difference in leaf $\mathrm{P}, \mathrm{Ca}$, and $\mathrm{Mg}$ content among the salinity treatments. Accordingly, no evidence of different foliar $\mathrm{Ca}$ concentrations was discovered for BC genotypes subjected to salinities ranging from 0 to 8 ppt in a previous study (Allen et al., 1997); however, progressive salinity increases did throw $\mathrm{Na} / \mathrm{Ca}$ ratios out of balance in greenhouse and field BC studies (Allen et al., 1997; Krauss et al., 2000). It is clear that although important individual foliar ions may remain unchanged with sea salt application, imbalances of specific ions, in lieu of absolute concentrations, may be more important.

Overall concentrations of $\mathrm{Na}$ among leaves of all Taxodium genotypes increased as sea salt concentration increased (Fig. 2), but to a much different degree among genotypes. For exam- ple, $\mathrm{Na}$ concentrations in $\mathrm{T} 302$ leaves increased from $0.1 \%$ in Treatment $\mathrm{C}$ to $0.37 \%$ in Treatment $\mathrm{H}$. The high salt rate created leaf $\mathrm{Na}$ concentrations in $\mathrm{BC}$ up to $5500\left(\mathrm{mg} \cdot \mathrm{L}^{-1}\right)$, or $0.55 \%$, which may have contributed to imbalances in $\mathrm{Na} / \mathrm{K}$ ratios. For comparison, Allen et al. (1997) reported foliar Na concentrations slightly greater than $1.0 \%$ for $\mathrm{BC}$ seedlings exposed to $8 \mathrm{ppt}$ floodwater salinity for over 3 months. $\mathrm{Na} / \mathrm{K}$ ratios in Taxodium leaves differed significantly among sea salt treatment (Fig. 3), increasing from 0.09 in leaf tissue of plants in $\mathrm{C}$ to 0.22 in leaf tissue of plants at the highest salt exposure $(\mathrm{H}) . \mathrm{Na} / \mathrm{K}$ ratios can freely exceed 1.0 at salinities as low as 2 ppt (Allen et al., 1997). Dilution of ions in the greater biomass of T302 might be at least a partial explanation for the elemental content of that genotype. However, because significant differences were found between $\mathrm{BC}$ and $\mathrm{MC}$ leaf elemental content, both with similar final weights, this may not be at odds with greater 


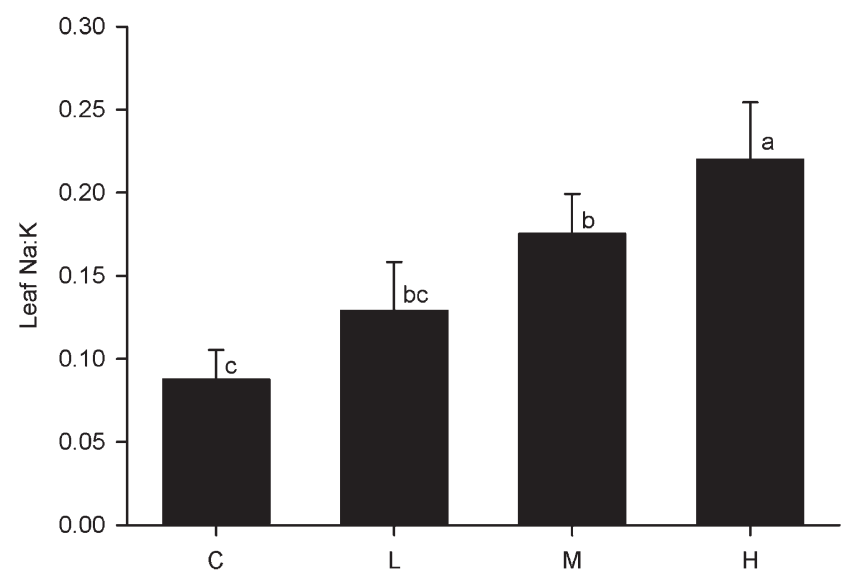

Fig. 3. Sodium/potassium $(\mathrm{Na} / \mathrm{K})$ ratios for all three Taxodium genotypes combined by sea salt application of 0 ppt (C), 1 ppt (L), 3.5 ppt (M), and 6 ppt (H) for 13 weeks, and then 0 ppt (C), 2 ppt (L), 7 ppt (M), and $12 \mathrm{ppt}(\mathrm{H})$ for an additional 12 weeks. Values are means of 24 samples. Bars represent 1 sD of the mean. Means with the same letter are not significantly different at the 0.05 level of probability according to Tukey's studentized range test.

salt tolerance by way of foliar ion exclusion of $\mathrm{Na}$ in $\mathrm{T} 302$ relative to $\mathrm{BC}$.

Rates of sea salt application in this study did not significantly affect the growth of Taxodium. Pezeshki (1990) also found that height growth, net photosynthesis, and stomatal conductance were unaffected when $\mathrm{BC}$ seedlings were watered with 3 ppt salinity for $60 \mathrm{~d}$. Overall, it appears that Taxodium has fair tolerance to transient exposures of salinity as long as leaching occurs within a few days of exposure. However, similar to our results, salt treatment through watering with 3 ppt did have a significant effect on the concentrations of leaf $\mathrm{Na}, \mathrm{K}$, and $\mathrm{S}$ as well as $\mathrm{Na} / \mathrm{K}$ ratios (Pezeshki, 1990). In our study, it was apparent that leaf $\mathrm{Na}$ concentration increased with increasing sea salt application rates as Taxodium became less adept at excluding Na. Furthermore, Pezeshki et al. (1988) reported a significant increase in $\mathrm{Na}, \mathrm{K}, \mathrm{Ca}$, and $\mathrm{Mg}$ concentration of leaf tissue of $\mathrm{BC}$ subjected to saltwater flooding relative to freshwater flooding. Other studies have suggested that $\mathrm{Na} / \mathrm{K}$ ratios provide a wonderful tool for selecting genotypes in $\mathrm{BC}$; ion ratios below 1.0 represent a relatively stress-free condition for non-halophytes (Wyn Jones et al., 1979). Increases in site salinity beyond those tolerable for BC quickly vectored foliar $\mathrm{Na} / \mathrm{K}$ ratios above 1.0 on field plantation sites south of New Orleans, LA (Krauss et al., 2000); ion ratios offer a tool to assist wetland scientists and arboriculturalists with selection of perspective Taxodium genotypes harboring greater tolerance to low salinity levels (Allen et al., 1997). Exclusion of $\mathrm{Na}$ from the foliage of MC and T302 is most promising and may be a primary reason why T302 demonstrated fair tolerance to salinity in past trials (Creech and Yin, 2003).

\section{Conclusions}

It appears that the salt tolerance of Taxodium was improved in a hybrid cross between T. distichum var. distichum (BC) and T. distichum var. mexicanum (MC) genotypes, at least as long as salinity is delivered in a specific way such as may be the case for deicing salts along roadsides. All the plants survived the salinity treatments, and the high salt rate failed to damage plants or to inhibit plant growth over 25 weeks. The benefits of using a hybrid cross (T302) that maintains greater biomass than $\mathrm{BC}$ or $\mathrm{MC}$ across a range of salinities must be weighed against the negative effects created by plagiotropic growth form relative to $\mathrm{BC}$ and $\mathrm{MC}$ and potentially reduced flood tolerance relative to $\mathrm{BC}$. The greater tolerance of $\mathrm{BC}$ to flooding may preclude major gains in salt tolerance improvement for use in coastal wetland restoration programs (Krauss et al., 2009); however, combining the best characteristics of different varieties of $T$. distichum may facilitate the production of favorable genotypes tolerant to a number of soil physical and chemical fluctuations for arboricultural operations.

\section{Literature Cited}

Allen, J.A. 1992. Cypress-tupelo swamp restoration in southern Louisiana. Restor. Manage. Notes 10:188-189.

Allen, J.A., J.L. Chambers, and D. McKinney. 1994a. Intraspecific variation in the response of Taxodium distichum seedlings to salinity. For. Ecol. Mgt. 70:203-214.

Allen, J.A., J.L. Chambers, and M. Stine. 1994b. Prospects for improving the salt tolerance of forest trees: A review. Tree Physiol. 14:843853.

Allen, J.A., J.L. Chambers, and S.R. Pezeshki. 1997. Effects of salinity on valdcypress seedlings: Physiological responses and their relation to salinity tolerance. Wetlands 17:310-320.

Allen, J.A., S.R. Pezeshki, and J.L. Chambers. 1996. Interaction of flooding and salinity stress on baldcypress (Taxodium distichum). Tree Physiol. 16:307-313.

Arnold, M.A. 2008. Landscape plants for Texas and environs. Sec. Ed. Stipes Pub. LLC, Champaign, IL.

Arnold, M.A. and G.C. Denny. 2007. Taxonomy and nomenclature of baldcypress pondcypress and Montezuma cypress. One, two or three species? HortTechnology 17:125-127.
Chen, Y., M. Wang, S. Wu, L. Liu, and S. He. 1987. Interspecific hybridization and breeding of genus Taxodium for fast-growing and alkaline tolerance. Nanjing Zhongshan Botanical Garden Research Papers 92-98.

Conner, W.H. 1994. The effect of salinity and waterlogging on growth and survival of baldcypress and Chinese tallow seedlings. J. Coast. Res. 10:1045-1049.

Conner, W.H., K.W. Krauss, and T.W. Doyle. 2007. Ecology of tidal freshwater forests in coastal deltaic Louisiana and northeastern South Carolina, p. 223-253. In: Conner, W.H., T.W. Doyle, and K.W. Krauss (eds.). Ecology of tidal freshwater forested wetlands of the southeastern United States. Springer, New York, NY.

Conner, W.H., I. Mihalia, and J. Wolfe. 2002. Tree community structure and changes from 19871999 in three Louisiana and three South Carolina forested wetlands. Wetlands 22:58-70.

Conner, W.H. and J.R. Toliver. 1990. Long-term trends in the baldcypress (Taxodium distichum) resource in Louisiana (USA). For. Ecol. Mgt. 33/34:543-557.

Craig, N.J., R.E. Turner, and J.W. Day, Jr. 1979. Land loss in coastal Louisiana (USA). Environ. Manage. 3:133-144.

Creech, D. and Y. Yin. 2003. Taxodium $\times$ 'Nanjing Beauty': A new landscape plant for the south. HortScience 38:1292-1293.

Denny, G.C. 2007. Evaluation of selected provenances of Taxodium distichum for drought, alkalinity and salinity tolerance. $\mathrm{PhD}$ diss., Texas A\&M University.

Flowers, T.J., P.F. Troke, and A.R. Yeo. 1977. The mechanism of salt tolerance in halophytes. Annu. Rev. Plant Physiol. 28:89-121.

Greenway, H. and R. Munns. 1980. Mechanisms of salt tolerance in nonhalophytes. Annu. Rev. Plant Physiol. 31:149-190.

Hook, D.D. 1984. Waterlogging tolerance of lowland tree species of the south. Southern J. Appl. For. 8:136-149.

Huang, L., X. Li, D. Zhang, Y. Chen, and X. Lu. 2006. Study on the growth of Taxodium. 'Zhongshansha 302' on hilly area. Journal of Jiangsu Forestry Science and Technology 33:6-9.

Integrated Taxonomic Information System. 2009. 3 Nov. 2010. <http:www.itis.gov/index.html>.

Krauss, K.W., J.L. Chambers, J.A. Allen, B.P. Luse, and A.S. DeBosier. 1999. Root and shoot responses of Taxodium distichum seedlings subjected to saline flooding. Environ. Exp. Bot. 41:15-23.

Krauss, K.W., J.L. Chambers, J.A. Allen, D.M Soileau, Jr., and A.S. DeBosier. 2000. Growth and nutrition of baldcypress families planted under varying salinity regimes in Louisiana, USA. J. Coast. Res. 16:153-163.

Krauss, K.W., J.L. Chambers, and D. Creech. 2007. Selection for salt tolerance in tidal freshwater swamp species: Advances using baldcypress as a model for restoration, p. 385-410. In: Conner, W.H., T.W. Doyle, and K.W. Krauss (eds.). Ecology of tidal freshwater forested wetlands of the southeastern United States. Springer, New York, NY.

Krauss, K.W., R.J. Howard, and T.W. Doyle. 2009 Is there evidence of adaptation to tidal flooding in saplings of baldcypress subjected to different salinity regimes? Environ. Exp. Bot. 67: 118-126.

Li, H. 2006. Study on genetic analysis on Taxodium Rich. using RAPD. MS thesis, Nanjing Agriculture University, Nanjing, PR China

Mattoon, W.R. 1915. The southern cypress. Bull. 272. U.S. Department of Agriculture, Washington, DC. McDonald, G.V., G.C. Denny, M.A. Arnold, D.L. Bryan, and L. Barnes. 2008. Comparative canopy 
damage among provenances of baldcypress associated with the presence of Cercosporidium sequoia (Ellis and Everth.) W.A. Baker and Partridge. HortScience 43:1703-1705.

Pezeshki, S.R. 1990. A comparative study of the response of Taxodium distichum and Nyssa aquatica seedlings to soil anaerobiosis and salinity. For. Ecol. Mgt. 33/34:531-541.

Pezeshki, S.R., R.D. DeLaune, and W.H. Patrick. 1988. Effect of salinity on leaf ionic content and photosynthesis of Taxodium distichum L. Am. Midl. Nat. 119:185-192.

Pezeshki, S.R., R.D. DeLaune, and W.H. Patrick, Jr. 1986. Gas exchange characteristics of bald cypress (Taxodium distichum L.): Evaluation of responses to leaf aging, flooding, and salinity. Can. J. For. Res. 16:1394-1397.

Pezeshki, S.R., R.D. DeLaune, and W.H. Patrick, Jr. 1987. Response of baldcypress (Taxodium distichum L. var. distichum) to increases in flooding salinity in Louisiana's Mississippi River Deltaic Plain. Wetlands 7:1-10.

SAS Institute, Inc. 2007. Online Doc 9.1.3. SAS Institute, Inc., 2002-2005, Cary, NC.

Templet, P.H. and K.J. Meyer-Arendt. 1988. Louisiana wetland loss: A regional water management approach to the problem. Environ. Manage. 12:181-192.

Townsend, A.M. 1989. The search for salt tolerant trees. Arboricultural J. 13:67-73.

Tsumura, Y., N. Tomaru, Y. Suyama, and S. Bacchus. 1999. Genetic diversity and differentiation of Taxodium in the south-eastern United States using cleaved amplified polymorphic sequences. Heredity 83:229-238.

Wicker, K.M., D. Davis, M. DeRouten, and D. Robert. 1981. Assessment of extent and impact of saltwater intrusion into the wetlands of
Tangipahoa Parish, Louisiana. Coastal Environments Inc., Baton Rouge, LA., pp. 59.

Wyn Jones, R.G., C.J. Brady, and J. Speirs. 1979. Ionic and osmotic regulation in plant cells, p. 63-103. In: Laidman, D.L. and R.G. Wyn Jones (eds.). Recent advances in biochemistry of cereals. Academic Press, London, UK.

Yu, C., Y. Yin, and J. Xu. 2009. Identification of Taxodium hybrids by SRAP analysis. Scientia Silvae Sinicae. 45:142-146.

Zhou, K., C. Jia, Y. Chen, Y. Yin, and Z. Sunday. 2000. Analysis on growth of Taxodium distichum and $T$. 'Zhongshansha' on the alkaline low-land. J. Jiangsu For. Sci. Tech. 27: $16-18$.

Zobel, B. and J. Talbert. 1984. Applied forest tree improvement. Waveland Press, Inc., Prospect Heights, IL. 